
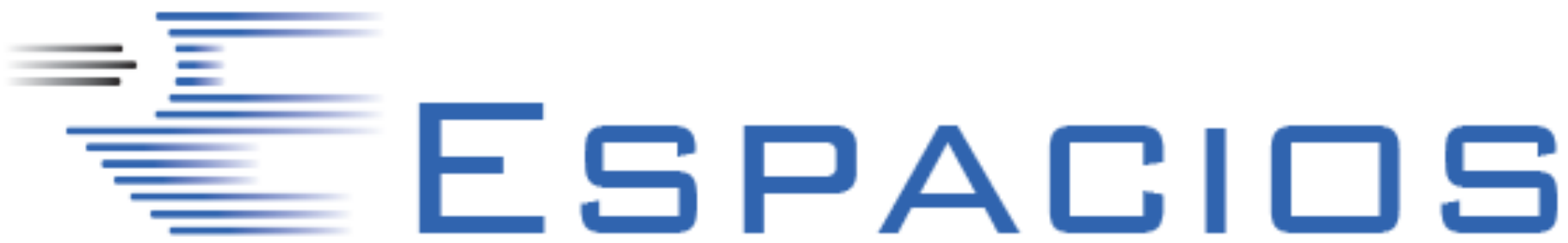

HOME

\title{
Renewable Energy Implementation Program Based on Local Wisdom
}

\section{Programa de implementación de energía renovable basado en la sabiduría local}

\author{
AKBAR, Muh. Firyal 1; KESMAWAN, Andri Putra 2; HARUN, Evan 3; NAHRUDDIN, Zulfan 4 \& MOHI, \\ Widya Kurniati 5
}

Received: 31/10/2018 • Approved: 05/02/2019 • Published 13/05/2019

\section{Contents}

1. Introduction

2. Methodology

3. Results

4. Conclusions

Acknowledgements

Bibliographic references

\section{ABSTRACT:}

The research viewed the implementation of the renewable energy program but applied different approach from previous studies that were based on cooperation and cost, this research has a different approach that is based on local wisdom in the implementation of renewable energy programs in Gorontalo. The research employs a combination of qualitative-quantitative, this study was conducted using the technique of dividing questionnaires to the public in four Indepenent villages Renewable energy in Gorontalo, the primary data of this study were also obtained through interviews with government officials in charge of renewable energy in the province of Gorontalo, public, and local Indigenous leaders. The value of local knowledge that can be adopted from this research is Ethics (sourced from the opposite Nungo) to act on all dimensions of program implementation, Obedience to authority (sourced from the opposite Butola) to act on the dimensions of the structuring, Public Access (Sourced from opposite Batato) play a role in public dissemination dimension, then the value of working Professionalism (sourced from the opposite Hutahutango) play a role in structuring the dimensions of the system and the allocation of program benefits and a fair division (sourced from the opposite Lambango) play a role in the allocation of the benefits of the renewable energy program. Implementation of a program of local

\section{RESUMEN:}

La investigación observó la implementación del programa de energía renovable pero aplicó un enfoque diferente al de estudios previos que se basaron en la cooperación y el costo, esta investigación tiene un enfoque diferente que se basa en la sabiduría local en la implementación de programas de energía renovable en Gorontalo. La investigación emplea una combinación de cualitativocuantitativo; este estudio se realizó utilizando la técnica de dividir cuestionarios al público en cuatro aldeas independientes. Energía renovable en Gorontalo, los datos primarios de este estudio también se obtuvieron a través de entrevistas con funcionarios del gobierno a cargo de fuentes renovables. Energía en la provincia de Gorontalo, líderes indígenas, públicos y locales. El valor del conocimiento local que puede adoptarse a partir de esta investigación es la ética (proveniente del opuesto Nungo) para actuar en todas las dimensiones de la implementación del programa, la obediencia a la autoridad (proveniente de la butola opuesta) para actuar sobre las dimensiones de la estructuración, el público El acceso (procedente de Batato opuesto) desempeña un papel en la dimensión de difusión pública, luego el valor del profesionalismo laboral (procedente de Hutahutango opuesto) desempeña un papel en la estructuración de las dimensiones del sistema y la asignación de los beneficios del programa 

professionalism, and a fair division of the benefits is the main finding in this study that provides novelty value on the concept of implementation program.

Keywords: Program Implementation, Local Wisdom, Renewable Energy, Rural Communities

y una división justa (fuente desde el lado opuesto de Lambango) desempeñan un papel en la asignación de los beneficios del programa de energía renovable. La implementación de un programa de aspectos del conocimiento local sobre las dimensiones de la ética, la adherencia a las autoridades, el acceso público, la profesionalidad laboral y una división justa de los beneficios es el principal hallazgo en este estudio que proporciona un valor novedoso en el concepto de programa de implementación.

Palabras clave: Implementación de programas, Sabiduría local, Energía renovable, Comunidades rurales

\section{Introduction}

Energy issues in Indonesia, as well as the global community, is very complex and full of political content that needs serious handling (Hasan, et.al, 2012; Gunningham, 2013). Included in the renewable energy optimization requires a special approach to identify problems with specific approach locally (Tasri \& Susilawati, 2014).

Approach to the development of renewable energy locally means necessary clearance can support from government policies. Measures regarding energy policy is to commercialize the energy is not used up as energy needs in the country who can influence the energy efficiency and a stable economic growth in a country (Ayres et. Al, 2007). To enable the achievement we need to hold various policy measures to be grouped in a pattern of intensification, conservation, indexing and diversification (Yustiningrum, 2017).

Diversification will enhance the diversification penganeka use of various types of energy in the country (Santoso \& Nuhung, 2018).

During this time to increase the diversity of Indonesia is still subsidized by the state (the state budget), thus becoming a very heavy burden for the government therefore the utilization of new and renewable energy sources needed to be developed through a series of different approaches between each country.

For comparison in Thailand renewable energy production is optimized through the implementation of energy programs based on cooperation with the company. For example, one company Talaad Thai produce 120 tons of waste per day, of which nearly $85 \%$ organic and therefore suitable for use in renewable energy, especially biogas production. Research conducted Ali et.al, (2012), in Thailand showed that organic waste is a major part of the total waste (more dari85\%), of which approximately $74 \%$ is vegetable and fruit waste, $8 \%$ is food waste, and $5 \%$ are waste from the flower market. Renewable energy-based approach to development cooperation with the private sector provide a significant impact to increase renewable energy production.

While Malaysia has a draft National Renewable Energy Policy that can help the country to achieve the target with cost-based pricing. Malaysia renewable energy policy. It then developed to further improve the structural attitude of the current policy of ensuring the effective implementation of large-scale renewable energy (Ong, et.al, 2016). As the resulting EBT consists of mini-hydro 290 MW, 330 MW biomass, biogas 100 MW, 200 MW of waste bins, solar and $65 \mathrm{MW}$. Malaysia is targeting $985 \mathrm{MW}$, or about 6\% of total electricity generation came from renewable energy sources by 2015.

The Malaysian government anticipates a strong progressive growth in renewable energy capacity by 2050 . Malaysia has also developed advanced hydrogen production technologies using renewable energy resources and sustainable to counter and reduce the cost of the country's electricity (Hosseini and Wahid, 2016). Malaysia strengthen our approach clear direction on the implementation of the program so that the cost-based optimization of renewable energy showed positive signs.

As for the Indonesian state contributes only 3\% for the utilization of renewable energy Hasan, et al. (2012), while Indonesia has the largest geothermal reserves in the world. One of the provinces with the potential to develop renewable energy is Gorontalo province has renewable energy resources such as various types; geothermal, hydropower, solar power, 
wind power, and biomass consisting of wood, agricultural waste (husk), and forest waste (coconut shell).

Gorontalo has a hydropower potential (hydro and mini-hydro) is very large and has not been used optimally Didik, et.al, et.al (2018), Bakhtyar, et al (2013), Bhattacharyya, SC (2013), This potential can generate electricity of $166.96 \mathrm{GWh}$. Then hydropower located around the river Bone has great potential, a maximum of $61.05 \mathrm{MW}$. Then hydropower potential located in District Tilamuta Boalemo district, sub-district and Paguat Lemito Pohuwato, as well as District Suwawa Bone Bolango District that have not been maximized. Therefore, research is needed to determine the implementation of government programs related Gorontalo efforts to use the potential of renewable resources in Gorontalo in terms of local knowledge. This is what distinguishes the approach taken Malaysia based fee based on research Ong, et.al, (2016), and Thailand with a renewable energy program based on private sector cooperation based on research Ali et.al, (2012), The research looked at different approaches of these two studies, this study showed the renewable energy program implementation approach based on local wisdom in Gorontalo.

\section{Methodology}

This type of research is the kind of research using a combination of qualitative-quantitative models. Location of the study conducted in four villages namely Tapada'a, Tulabolo village, Liyodu village, and the village Dulamayo. These four villages implement program the development of an energy independent village in Gorontalo. This study was conducted using questionnaires division techniques to the public on four villages namely Tapada'a, Tulabolo village, Liyodu village, and the village Dulamayo. In addition, the study primary data obtained through interviews with informants about their knowledge of the implementation of government programs Gorontalo in the utilization of renewable energy. Informant determined by purposive sampling, that the Head of Department, Secretary, Head of Renewable Energy at Department of Mineral Resources and Energy of Gorontalo province, public and local Indigenous People, this is done for seeing fit between prospective informants selected with the focus of research being conducted.

\section{Results}

\subsection{Implementation of the Renewable Energy Program in Energy Independent Village}

The results of the interview at the Department of Mineral Resources and Energy of Gorontalo Province, showed that the readiness of organizations affected by the policies of the central or master plan drawn up by the central government such as the renewable energy policy of national $25 \%$ local governments allocate energy exclusively on renewable energy up to the year 2025. Therefore the development of renewable energy policy in the region focusing on the area or location that has not been electrified in other words, off-grid locations including State Electricity Company (PLN).

socialization conducted involving the entire community and the village government along these activities acquire public enthusiasm even in the village Liyodu incorporate renewable energy into the development program for the existence Solar Power Plant (PLTS) form village budget very beneficial for the community. Dissemination of public information disseminated before implementation development in location development of renewable energy, the socialized is the basic principle of the development of Renewable Energy which aims to give more knowledge and a sense of security to people who receive coverage lighting the renewable energy with a focus on the location of rural areas not reached by the electric current by PLN.

In the selection of priority locations to prior recipients an initial survey which determined that the site will not be entered by PLN within 2-3 years in the future after it conducted a feasibility study data collection after it was established institutions of local people equipped with technical training in the form of a number of 3-5 people organization consisting of 
structures chairman, secretary and technical operator. determining the location based on the location of gristle and dark and had a great urgency and usefulness to society if the location of renewable energy generation in this case PLTS held since these locations do not yet have electricity.

Structuring Systems in Priority Area refers to the results of a feasibility study has been done and arrangements were made because they do not follow the flow path within the home included in off-grid locations that have a distance apart with a limited number of 100 heads of household. Structuring the location of the beneficiary of the renewable energy program is aimed at a location away from the infrastructure and power facilities so that when the location has electrified it is no longer using renewable energy.

Based on the results of interviews known of the allocation of benefits economically received by the community it is seen from the use of the cost of electricity obtained from the use of the generator is much more expensive than the economic benefits derived from the use of renewable energy in a single night costs the use of generators can be cost of 1 month for energy renewable economically very significant benefits of renewable energy. Besides the social benefits of renewable energy is increasing the productivity of society as seen from carpentry activities to do after their renewable energy. then there are inputs for the improvement of renewable energy programs in Gorontalo is a request to increase the rated power of the power is still less and less stable. above there is criticism from the public related to budgeting unit PLTS rated high while very minimal use only one home. This is certainly a power input for repairs and improvements in the allocation of benefits to the community.

Figure 1

Development of Renewable Energy Program implementation in Gorontalo

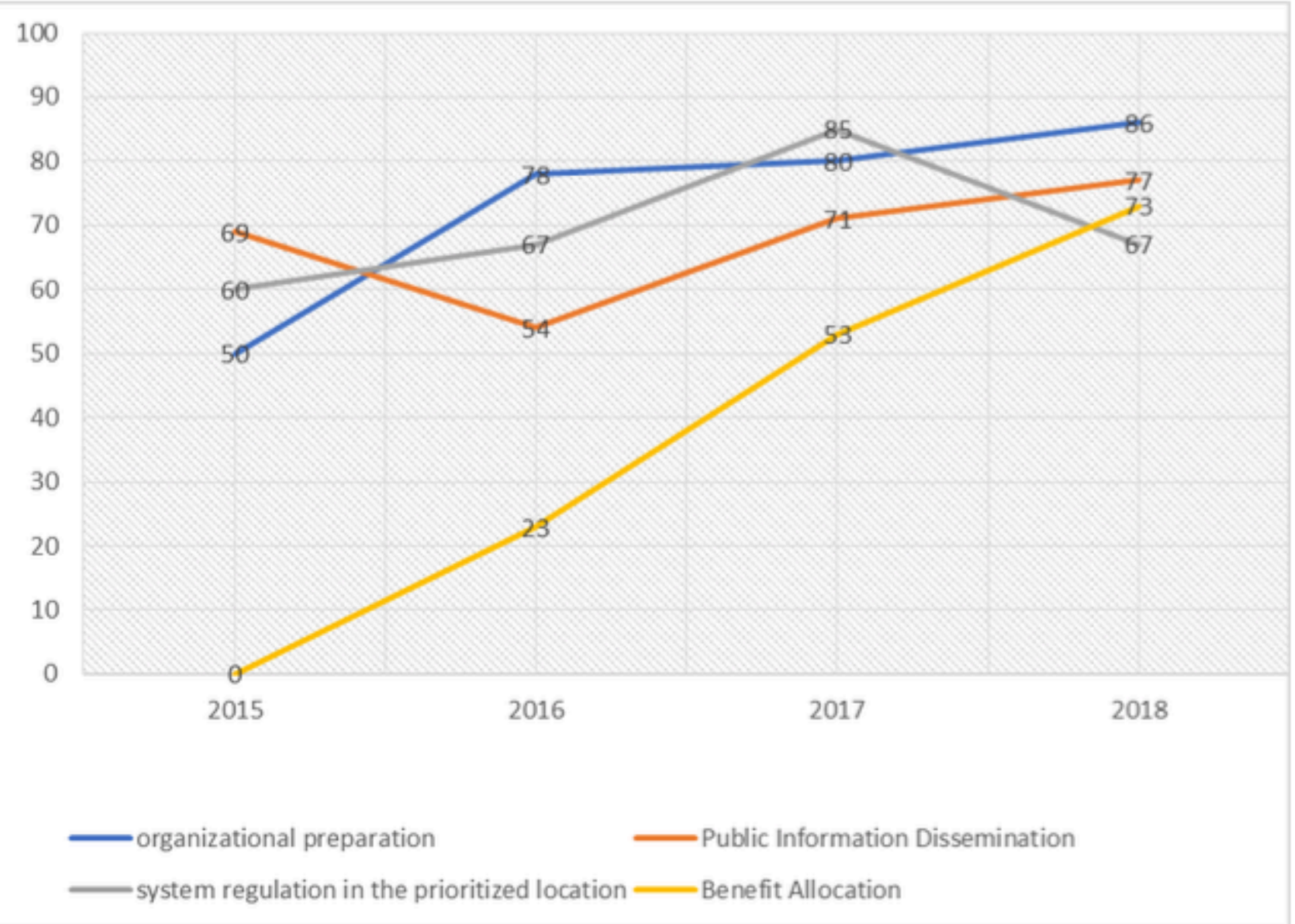

Based on the Figure 1. There is a performance improvement program from 2015 to 2018 year it is seen from the dimensions of organizational preparation, dissemination of public information, and the allocation of benefits, but there are issues to reform the system in a location this is because the program prioritiesrenewable energy program is aimed at a 
location away from the infrastructure and power facilities, especially in the village some distance away so that the number of families who facilitated limited other than that the demand for additional power is considered still lacking in terms of capacity and less stable the community input receiver program not accommodated.

\subsection{Local wisdom aspect in the implementation of the Energy Program}

Participatory development encourages a conscious and planned absorption of local knowledge, implementation of government programs implemented continuously making the community as a partner by facilitating all the needs of the community in addition to that, the government is also involved in solving social problems associated with the implementation of renewable energy programs in Gorontalo, $\mathrm{p}$ the aim of this in order to minimize social conflicts that occurred during program execution.

There is still a lack of synergy between the government and the community in development at the local level are highlighted in this study because the local kaarifan less accommodated. Pembagunan embodiment village must accommodate the interests of the local community, including the origin of culture. All sorts of programs launched should lead to the realization of the recognition of the right origin legally recognized and legal form of central and local government regulation or lowest levels ie village government regulations.

Development Consultation Teams medirectly involve local organizations we recruit them they trained community education and training center of Gorontalo Regional Government, consisting of the Chairman, Sekeretaris and technical officers. A generator 53 operators. Through dues money was used for operations is not up to us, we just mengaawasi example of service no installation of 100 homes could be powered by renewable energy.

Indigenous Council approved the program implemented, Participants discuss the draft plan prepared energy program. Suggestions and feedback given traditional institutions in the development of renewable energy sources Location conducted in meetings that discuss the allocation of local resources involved. Policies that can be taken by the community through the characters in the development of location priorities are when programs are in contact with customs such as communal land, buildings and ancestral heritage, norms and culture, as long as the program does not conflict with the local wisdom that the development program can be resumed. There are some behaviors that arranged through the local culture so that appropriate implementation of renewable energy and does not conflict with local wisdom.

Table 1

The absorption of local values on implementing the program

\begin{tabular}{|l|c|c|c|c|}
\hline $\begin{array}{l}\text { Local Wisdom } \\
\text { Values }\end{array}$ & $\begin{array}{c}\text { preparation } \\
\text { Organizations }\end{array}$ & $\begin{array}{c}\text { Public } \\
\text { Information } \\
\text { Dissemination }\end{array}$ & $\begin{array}{c}\text { structuring } \\
\text { System }\end{array}$ & Benefit allocation \\
\hline $\begin{array}{l}\text { Nungo = No ethical } \\
\text { manners }\end{array}$ & 1.17 & 1.67 & 1.33 & 1.5 \\
\hline $\begin{array}{l}\text { Butola = Opposing } \\
\text { or not obey the } \\
\text { orders of superiors } \\
\text { or officials of State. }\end{array}$ & 2.1 & 2 & 1.67 & 1.17 \\
\hline $\begin{array}{l}\text { Batato = Open the } \\
\text { land without } \\
\text { permission }\end{array}$ & 1.67 & 1.33 & 1.67 & 1.33 \\
\hline & & & & \\
\hline
\end{tabular}




\begin{tabular}{|l|c|c|c|c|}
\hline $\begin{array}{l}\text { Hutahutango } \\
\text { Abuse of authority }\end{array}$ & 1.17 & 1.17 & 2.7 & 1.5 \\
\hline $\begin{array}{l}\text { Lambango }= \\
\begin{array}{l}\text { Stepping over the } \\
\text { rights of others }\end{array}\end{array}$ & 1.33 & 1.67 & 1.5 & 1.67 \\
\hline
\end{tabular}

According to the table 1. Can display local absorption values in the implementation of the program the Department of Mineral Resources and Energy of the Province of Gorontalo, their scores are included in the high category with a score of 2.7 which is the value Hutahutango $=$ Abuse of authority on the structuring dimension, but overall indicators implementation of renewable energy programs included in the low category, only on Butola (Opposing or not obey orders of superiors or officials of State) on the dimensions of organizational readiness in medium category, while local values Nungo $=$ No ethical manners and Lambango $=$ Stepping over the rights of others included in the category of low values in all dimensions.

The acceptance of the importance of local value in the implementation of renewable energy has been absorbed by the public during the culture inherent in their lives, each exercising their program of attention to local customs and culture. Structuring systems in the high category in the local value Hutahutango = penyalagunakan authority for community involvement has been limited by their kepanitian formed with the number 5 while the energy division is limited by the number of heads of household and coverage area of renewable energy is channeled.

Conditions and limitations result in the assumption that the use of renewable energy is limited to certain people who have a favorable location. The emergence of social control of local knowledge is an integral part of participatory development (Rydin and Pennington, 2000; Botes \& Van Rensburg, 2000), as well as the involvement of local wisdom to the program that makes the community as a target implementation of government programs in the sense of effort bottom up more prioritized as input that truly represents the interests of the community naturally without damaging the social fabric therein (Zakus \& Lysack, 1998; Marshall, 2008), participation activities were also conducted with public consultation through the institution of the local customs are meant to prepare communities to deal with problems will be addressed by providing insight and direction on the implementation of the renewable energy program that takes into account local values in implementation of programs involving public participation as beneficiaries of the renewable energy program.

\subsection{Local Wisdom For New Approach Implementation Program}

Local knowledge serves to set the relationship on processing resources in a society. It is associated with a set of actions or measures that have a binding rule in a society that is in a certain region, the programs offered by the government to have the resistance of the aspects of local knowledge and also could otherwise have a stake in supporting government programs. In this research, local knowledge became a support in the implementation of renewable energy programs, the institutional support provided input for the implementation of renewable energy programs through socialization held Gorontalo government so that people can participate in and contribute to the success of the program. Here groove local wisdom approach to the implementation of renewable energy programs in Gorontalo.

Figure 2

Flow of local wisdom approach to the implementation of the program 
Local Wisdom Values

- Ethics (Sourced from the opposite Nungo)

- Obedience to authority (sourced from the opposite Butola)

- Open access (Sourced from opposite Batato)

- Professionalism (sourced from the opposite Hutahutango)

- Equitable benefitsharing (sourced from the opposite Lambango)

Renewable Energy

Program Implementation:

- preparation Organizations

- Public Information Dissemination

- structuring System

- Benefit allocation
The success of the implementation of renewable energy programs

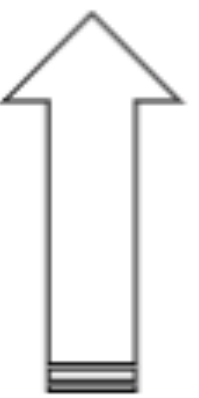

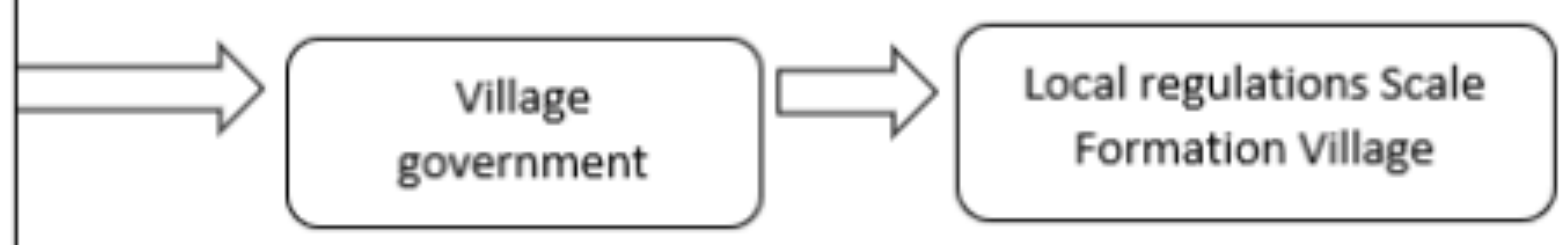

Based on the above plot can be understood that the value of local knowledge that can be adopted is of this research is Ethics (sourced from the opposite Nungo ) Plays a role in every dimension of program implementation, Obedience to authority (sourced from the opposite Butola ) To act on the dimensions of the structuring, Public Access (Sourced from opposite Batato) play a role in the dimensions of the dissemination of public, then the value of professionalism of the work (sourced from the opposite Hutahutango) to act on the dimensions of the structuring and allocation of program benefits and Equitable distribution (derived from the opposite Lambango) play a role in the allocation of the benefits of the renewable energy program.

The values of local wisdom can be absorbed by the village administration that initially is informal rules that limit the abuse of authority and responsibility of program managers and ensure fairness in the implementation of renewable energy programs into the formal regulations adopted into the regulatory scale local village so has the strength and legitimacy limited to the territory of the village and also get approval from the local authorities.

Approach local wisdom as a new standpoint has dimensions of program implementation, among others: (1) Ethics, the implementation of government programs can be seen from the moral measure of the officers involved in a series of program implementation activities ranging from the preparation of the Organization, iseminasi Public Information, reform the system and the allocation of benefits. Ethics in the implementation of the program provide decision and policy development and implementation of a humanist and not ignore the culture and keep the country where such programs because they diimpelementasikan each country has a different ethical perceptions (Bommer, et.al, 1987; Edejer, 1999). It's hard to ignore local knowledge as a social tool that has long been attached to the center of a community, local knowledge is able to control the attitude of the program managers and communities as beneficiaries of the program. (2) Obedience to authority, namely the respect, the attitude of respect for others and the environment, comply with and obey the regulations in force are elements that draw together the public personalities who have local 
knowledge that is civilized and cultured (Ray, 1996; Bottoms \& Tankebe, 2012; Rahman, 2015). The positive side emerging from the personality that upholds the values of local wisdom is capable of performing their duties and do not shy away if it receives the sanction of the offense committed. (3) Open access, public awareness of the importance of obtaining information that is poorly understood as a form of curiosity about the changes they derive from the implementation of the program does have a social impact, economic, or environmental (Rich, et.al, 1995), open access is an actor role, department, until the pressure on local agencies (Newman and Dale, 2005). Understanding and role of the community is very important because as a benchmark for the government in carrying out this policy was successful in implementing the program is transparent and accountable to public access in order to control the execution of the program. (4) Professionalism, run programs based on authority is not over and is not reduced, the cutting edge especially in the success of programs for the community is a professional officer. Violation concerns to local cultural values will affect the performance (Reason, 1998). The authority is a deposit which must be maintained because of the tendency of the local culture in the community based on the results of this study are not taking the authority of others it is more significant in maintaining the integrity of themselves did not work that out duties and functions. (5) Equitable benefit-sharing, people who understand the local wisdom deeply attached to culture cared for their local agencies but uneven implementation of the program will lead to social problems and distrust in the community so that the program will be interrupted in the event organization. Fairness in receipt of benefits from the resources exploited in the society must get uniform distribution in the form of social, economic, and political (Hayden, 2007; Justino, 2012; Sikor, 2013). This benefit-sharing dimension focuses on the forms of benefit sharing and equitable distribution of program benefits enjoyed by people who had been promised by the government.

Finally, this study finds a new angle implementation of aspects of local knowledge that is specifically used as approach although of general literature stated that the implementation of the policies outlined in the program event is a continuation of the process of formulating and establishing policies, various pastures of experts on the implementation of the program has been presented including Elmore, (1978); Durlak, (1998); Gendreau, et.al, (1999), found common ground on the implementation of policies that can be defined as actions carried out, either by individuals or groups of governments, which is oriented to the achievement of the objectives outlined in the policy decision. There is also the standpoint of policy implementation of the policy aspects of local wisdom has been done between (Blackwell \& Colmenar, 2000; Kusumasari \& Nature, 2012), but a different perspective in view of implementation of the program from the aspect of local wisdom found in this study include the dimensions of Ethics, Obedience the authorities, Public access, working professionalism, and a fair division of the benefits.

\section{Conclusions}

Based on this research it was found that the implementation of the program can be in contact with local knowledge when the program entered into the realm of such indigenous communal land, buildings and ancestral heritage, local cultural norms, as long as the program does not conflict with the local wisdom of the development program can be resumed. The value of local knowledge that can be adopted is of this research is Ethics (sourced from the opposite Nungo) Plays a role in every dimension of program implementation, Obedience to authority (sourced from the opposite Butola) To act on the dimensions of the structuring, Public Access (Sourced from opposite Batato) play a role in the dimensions of the dissemination of public, then the value of professionalism of the work (sourced from the opposite Hutahutango) to act on the dimensions of the structuring and allocation of program benefits and Equitable distribution (derived from the opposite Lambango) play a role in the allocation of the benefits of the renewable energy program. Implementation of a program of local knowledge aspects of the dimensions of Ethics, Adherence to the authorities, Public Access, working professionalism, and a fair division of the benefits is the main finding in this study that provides value kebaharuan on the concept of program implementation. 


\section{Acknowledgements}

We gratefully acknowledge the funding from USAID through the SHERA program - Centre for Development of Sustainable Region (CDSR).

\section{Bibliographic references}

Ali, G., Nitivattananon, V., Abbas, S., \& Sabir, M. (2012). Green waste to biogas: Renewable energy possibilities for Thailand's green markets. Renewable and Sustainable Energy Reviews, 16(7), 5423-5429. http://dx.doi.org/10.1016/j.rser.2012.05.021

Ayres, R. U., Turton, H., \& Casten, T. (2007). Energy efficiency, sustainability and economic growth. Energy, 32(5), 634-648. https://doi.org/10.1016/j.energy.2006.06.005

Bakhtyar, B., Sopian, K., Zaharim, A., Salleh, E., \& Lim, C. H. (2013). Potentials and challenges in implementing feed-in tariff policy in Indonesia and the Philippines. Energy policy, 60, 418-423. https://doi.org/10.1016/j.enpol.2013.05.034

Bhattacharyya, S. C. (2013). Rural electrification experience from South-east Asia and South America. In Rural Electrification Through Decentralised Off-grid Systems in Developing Countries (pp. 157-184). Springer, London.

Blackwell, A. G., \& Colmenar, R. (2000). Community-building: from local wisdom to public policy. Public Health Reports, 115(2-3), 161.

Bommer, M., Gratto, C., Gravander, J., \& Tuttle, M. (1987). A behavioral model of ethical and unethical decision making. Journal of business ethics, 6(4), 265-280.

Botes, L., \& Van Rensburg, D. (2000). Community participation in development: nine plagues and twelve commandments. Community Development Journal, 35(1), 41-58. https://doi.org/10.1093/cdj/35.1.41

Bottoms, A., \& Tankebe, J. (2012). Beyond procedural justice: A dialogic approach to legitimacy in criminal justice. The journal of criminal law and criminology, 119-170.

Didik, H., Bambang, P. N., Asep, S., \& Purwanto, Y. A. (2018, May). Sustainability Challenge of Micro Hydro Power Development in Indonesia. In IOP Conference Series: Earth and Environmental Science (Vol. 147, No. 1, 12p.

Durlak, J. A. (1998). Why program implementation is important. Journal of Prevention \& Intervention in the community, 17(2), 5-18. https://doi.org/10.1300/J005v17n02_02

Edejer, T. T. T. (1999). North-South research partnerships: the ethics of carrying out research in developing countries. BMJ: British Medical Journal, 319(7207), 438.

Elmore, R. F. (1978). Organizational models of social program implementation. Public policy, 26(2), 185-228.

Gendreau, P., Goggin, C., \& Smith, P. (1999). The forgotten issue in effective correctional treatment: Program implementation. International Journal of Offender Therapy and Comparative Criminology, 43(2), 180-187. https://doi.org/10.1177\%2F0306624X99432005

Gunningham, N. (2013). Managing the energy trilemma: The case of Indonesia. Energy Policy, 54, 184-193. https://doi.org/10.1016/j.enpol.2012.11.018

Hasan, M. H., Mahlia, T. M. I., \& Nur, H. (2012). A review on energy scenario and sustainable energy in Indonesia. Renewable and Sustainable Energy Reviews, 16(4), 2316-2328.

https://doi.org/10.1016/j.rser.2011.12.007

Hayden, C. (2007). Taking as giving: Bioscience, exchange, and the politics of benefitsharing. Social Studies of Science, 37(5), 729-758.

https://doi.org/10.1177/0306312707078012

Hosseini, S. E., \& Wahid, M. A. (2016). Hydrogen production from renewable and sustainable energy resources: promising green energy carrier for clean development. Renewable and Sustainable Energy Reviews, 57, 850-866. https://doi.org/10.1016/j.rser.2015.12.112 
Justino, P. (2012). Shared societies and armed conflict: Costs, inequality and the benefits of peace. IDS Working Papers, 2012(410), 1-23. https://doi.org/10.1111/j.20400209.2012.00410.x

Kusumasari, B., \& Alam, Q. (2012). Local wisdom-based disaster recovery model in Indonesia. Disaster Prevention and Management: An International Journal, 21(3), 351-369. http://dx.doi.org/10.1108/09653561211234525

Marshall, G. (2008). Nesting, subsidiarity, and community-based environmental governance beyond the local scale. International journal of the Commons, 2(1), 75-97.

Newman, L., \& Dale, A. (2005). The role of agency in sustainable local community development. Local environment, 10(5), 477-486.

https://doi.org/10.1080/13549830500203121

Ong, P. Y., Chin, C. M., \& Yap, E. H. (2016). Reviewing Malaysia's Renewable Energy Policies: A Management Framework Perspective. Journal of Clean Energy Technologies, 4(6).

Rahman, F. (2015). Internet and Kyais in Indonesia: Negotiation of Authority in a Mediatized Environment. Online-Heidelberg Journal of Religions on the Internet, 9.

http://dx.doi.org/10.11588/rel.2015.0.26252

Ray, D. I. (1996). Divided sovereignty: traditional authority and the state in Ghana. The Journal of Legal Pluralism and Unofficial Law, 28(37-38), 181-202.

https://doi.org/10.1080/07329113.1996.10756479

Reason, J. (1998). Achieving a safe culture: theory and practice. Work \& Stress, 12(3), 293306. https://doi.org/10.1080/02678379808256868

Rich, R. C., Edelstein, M., Hallman, W. K., \& Wandersman, A. H. (1995). Citizen participation and emprowerment: The case of local environmental hazards. American journal of community psychology, 23(5), 657-676.

Rydin, Y., \& Pennington, M. (2000). Public participation and local environmental planning: the collective action problem and the potential of social capital. Local environment, 5(2), 153-169. https://doi.org/10.1080/13549830050009328

Santoso, H., \& Nuhung, I. A. (2018). Prospects of Renewable Energy Development Within Remote or Rural Areas in Indonesia. In Transition Towards 100\% Renewable Energy (pp. 421-432). Springer, Cham.

Sikor, T. (2013). The justices and injustices of ecosystem services. In The Justices and Injustices of Ecosystem Services (pp. 24-28).

Tasri, A., \& Susilawati, A. (2014). Selection among renewable energy alternatives based on a fuzzy analytic hierarchy process in Indonesia. Sustainable Energy Technologies and Assessments, 7, 34-44. https://doi.org/10.1016/j.seta.2014.02.008

Yustiningrum, R. E. (2017). The Dynamics of Policy and Energy Issues in Indonesia. In Foreign Policy and Energy Security Issues in Indonesia (pp. 21-47). Springer, Singapore.

Zakus, J. D. L., \& Lysack, C. L. (1998). Revisiting community participation. Health policy and planning, 13(1), 1-12. https://doi.org/10.1093/heapol/13.1.1

1. Department of Public administration, Faculty of Social and Political Science, Universitas Muhammadiyah Gorontalo, Indonesia. e-mail: firyalakbar@umgo.ac.id

2. Department of management and public policy, Faculty of Social and Political Science, Universitas Gajah Mada, Indonesia. e-mail: andriputrakesmawan@gmail.com

3. Electrical engineering, Faculty of Engineering, Universitas Negeri Gorontalo, Indonesia. e-mail:

ervanharun@ung.ac.id

4. Department of Government Science, Faculty of Social and Political Science, Universitas Muhammadiyah Makassar, Indonesia. e-mail: zulfan.nahruddin@unismuh.ac.id

5. Department of Public administration, Faculty of Social and Political Science, Universitas Muhammadiyah Gorontalo, Indonesia. e-mail: widyakurniati@umgo.ac.id 
[In case you find any errors on this site, please send e-mail to webmaster] 